MAHATHIR'S ISLAM 


\section{MAHATHIR'S ISLAM}

Mahathir Mohamad on Religion

and Modernity in Malaysia

\section{Sven Schottmann}

\section{HWA}

University of Hawai'i Press

Honolulu 
(C) 2018 University of Hawai'i Press

All rights reserved

Printed in the United States of America

$232221201918 \quad 6 \quad 6543221$

\section{Library of Congress Cataloging-in-Publication Data}

Names: Schottmann, Sven, author.

Title: Mahathir's Islam: Mahathir Mohamad on religion and modernity in Malaysia/Sven Schottmann.

Description: Honolulu: University of Hawai'i Press, [2018] | Includes bibliographical references and index.

Identifiers: LCCN 2018001939 | ISBN 9780824876470 (cloth ; alk. paper)

Subjects: LCSH: Mahathir bin Mohamad, 1925-Religion. | Mahathir bin

Mohamad, 1925-Political and social views. | Islam and state-Malaysia. |

Malaysia-Politics and government.

Classification: LCC DS597.215.M34 S36 2018 | DDC 959.505/4092-dc23

LC record available at https://lccn.loc.gov/2018001939

University of Hawai'i Press books are printed on acid-free paper and meet the guidelines for permanence and durability of the Council on Library Resources.

Cover Photo @ 2010 Tara Sosrowardoyo. All rights reserved. 